\title{
Specific Roles of Builders in Building Information Modelling Processes
}

\author{
Oluseye Olugboyega
}

\begin{abstract}
Published online: 25 January 2019
To cite this article: Oluseye Olugboyega (2018). Specific roles of builders in Building Information Modelling processes. Journal of Construction in Developing Countries, 23(2): 27-42. https://doi.org/10.21315/jcdc2018.23.2.3.

To link to this article: https://doi.org/10.21315/jcdc2018.23.2.3

Abstract: Building Information Model is developed by integrating all information from project team members at each stage into a single repository that can easily be deposited, retrieved, edited and shared. Collaboration between the designers and builders is necessary to confirm the correctness of the design intent and concept before commencing the construction process. This study examined the specific roles of builders by examining the information required from builders in Building Information Modelling (BIM) processes. A total of 132 questionnaires filled by the respondents were used for analysis using the Relative Importance Index. The findings show that the role of builders in BIM is the coordination of 3-dimensional (3D) models and the simulation of the construction programme and construction methodology. The study concludes that the specific roles of builders in BIM processes are to detect information clashes and simulate the construction process in a sequential order.
\end{abstract}

Keywords: Building Information Modelling, Building Information Model, Construction and management model, Information contents of Building Information Model, Builders

\section{INTRODUCTION}

Inadequate information, ineffective communication and fragmentation in the design and construction process are the main drivers for Building Information Modelling (BIM). For BIM to serve its purpose of fostering collaboration among the construction professionals and integrating the design and construction process, it has to be developed by a project team. Bullinger et al. (2010) states that a BIM is developed by integrating all information from project team members at each stage into a single repository that can easily be deposited, retrieved, edited and shared. BIM is about teamwork to develop shared knowledge resources for project decisions throughout the project lifecycle (Arcadis, 2015). The Associated General Contractors of America (AGCA) (2006) maintains that a collaborative project team is required to optimise BIM efficiencies, where team members provide one another with information that will allow the team to work faster, better and cheaper. BIM aids quick and accurate communication among the project team members and as a project delivery process allows the participation of design and construction teams to their highest level of expertise in the design process through close collaboration and sharing of information (The Construction Users Roundtable [CURT], 2010). Although, BIM fosters collaboration among the project team members, yet it does not change their traditional responsibilities and only adds to them (AGCA, 2006). According to Arcadis (2015), the value of BIM is associated with the specific roles of BIM team

Department of Building, Obafemi Awolowo University, lle-Ife, NIGERIA

Corresponding author: oolugboyega@yahoo.com 
and its benefits is revealed in the sum of all the models developed by the members of the team. AGCA (2006) noted that the success of a project depends on the system of checks and balances in a project brought about by the involvement of the builders' right from the design stage.

The traditional process of exchanging information among parties at different project phases is error-prone. CURT (2010) observed that redundant efforts may take place during the design and construction process if builders are not involved early in the project because of the problems of buildability of design concepts. The communication between the designers and builders must be recognised and accommodated by BIM processes regardless of the medium of communication. This relationship is necessary to confirm the correctness of the design intent and concept before commencing the construction process (AGCA, 2006).

Numerous studies have explored the concept of BIM, BIM implementation and protocol and information contents of BIM. Jung and Joo (2011) developed a framework for practical BIM implementation, Chen (2007) developed an Object Model Framework (OMF) for interface management in building information models that presents a data structure and dependencies of interface information for modelling. CURT (2010) developed a BIM roles and responsibilities matrix for defining roles at various points along project timeline. Construction Industry Council (2013) developed a standard protocol for developing building information models in projects. The protocol identifies the building information models that are required to be produced by members of the project team and puts into place specific obligations and limitations to the use of the models. Also, Succar (2008) introduced multi-dimensional BIM framework, a research and delivery foundation for industry stakeholders that maps domain dynamics and allows industry stakeholders to understand underlying knowledge structures and negotiate BIM implementation requirements. However, there is lack of relevant research work on the type of information necessary to be in a discipline-specific model to be developed by the builder as a member of a project team in BIM.

In BIM, project team members are required to collaborate and share information at various stages of the project. Nikumbh and Pimplikar (2014) argued that every construction project demands the full attention and professionalism of its project team. Therefore, this study aims to identify the specific roles of builders in BIM processes by identifying and examining information required from builders at various stages of BIM-based construction projects. The collaboration among the project team members in a BIM-based project is not a one-off thing but a process. $\mathrm{BIM}$ requires a lot of roles and responsibilities and also requires the integration of discipline-specific models to develop a master model known as the Building Information Model. Hence, there is a need for the project team members working on different models to know the required information to be supplied at each stage of integration. Builders are the professionals that are responsible for the construction of building projects, without them building designs concepts cannot be realised: therefore, it is important to identify and understand the specific roles of builders in BIM processes and to identify the stages in the project lifecycle where those roles are to be performed. 


\section{BACKGROUND}

\section{Information Contents of Building Information Model}

A Building Information Model is the virtual model of a building which contains precise geometry, spatial relationships, geographic information, quantities, cost estimates, material schedules and project schedules needed to support the design and construction activities (Eastman et al., 2008). CURT (2010), Royal Institute of British Architects (RIBA) (2012), Specialist Engineering Contractors' (SEC) Group and National Specialist Contractors' Council (NSCC) BIM Working Group (2013), Smith (2014) and Arcadis (2015) note that a Building Information Model consists of integrated but distinct individual information models and that it can be developed by connecting the individual models together on a compatible BIM platform to generate a Building Information Model known as "Federated Building Information Model" or by integrating the discipline-specific models together on a common BIM platform to generate an "Integrated Building Information Model" or integrating the discipline-specific models on industry standard platform such as Construction Operation Building Information Exchange (COBie) and Industry Foundation Classes (IFC) to generate a model known as "Standard Federated Building Information Model".

National Building Information Modelling Standard (2007) points out that the development of a Building Information Model for a project should be based on the project goals, the project characteristics and the capabilities of the project team members. According to AGCA (2006), the information content of a Building Information Model is the responsibility of the project team. National Building Information Modelling Standard noted that the project team in BIM should consist of the owner, architect, builder, engineers, major specialty contractors and facilities manager and the team must identify, define and plan appropriate information to be modelled in details. This systematic multidisciplinary effort is required to enhance the value of a construction project starting from the design stage (Rangelova and Traykova 2014). The deliverables expected from BIM team as identified by AGCA (2006), National Building Information Modelling Standard (2007), Khanzode et al. (2008), Succar (2008), CURT (2010) and Construction Industry Council (CIC) (2013) include architectural information models, fabrication models, cost information models, structural information models, facility management models, construction and management information models and electrical and mechanical information models.

Building project lifecycle stages include planning, design, construction and operation and maintenance stages; each stage encompasses a lot of information to be developed and exchanged among various project participants. Although, the goals set out by the BIM team will determine the information to be modelled and the level of details in a Building Information Model (Khanzode et al., 2008). National Building Information Modelling Standard (2007) states that the information required and level of details in a Building Information Model must be defined and understood so that the BIM team members will know the information required from them. CIC (2013) suggests that the information requirements for a project define how a Building Information Model must be developed without changing the information contents of each discipline-specific model and that it should suit the needs of the project. 


\section{Builders and the Building Information Model}

Construction and management information models as a constituent of a Building Information Model and to be developed by the project builder must have the highest level of detail in a Building Information Model as it must contain information such as construction methodology and other project management information (CURT, 2010). AGCA (2006) believes that it is the responsibility of the builder to provide in quantifiable terms the resources required to implement a project to owners and team members. CURT (2010) argues that a Building Information Model cannot photo-realistically represent the completed project nor complete the project by itself and that a construction plan showing the construction means and methods is required from the builder to achieve this because of the need to complete the project economically and timely and the need for effective coordination of the tradesmen on site. AGCA (2006) opines that builders can use BIM to assist with the scope of work, value engineering and sequencing of construction and demonstration of construction methods. Traditionally, it is the responsibilities of the builder to prepare the buildability and maintainability reports, the construction methodology, the construction health and safety plan, the quality management plan, change management plan, optimisation of energy and resource consumption plan, environmental impact mitigation plan, sustainability analysis, function analysis and the construction programme (Kam and Fisher, 2004; Jensen, 2008; Hungu, 2013; Rangelova and Traykova, 2014; Kuroshi, 2015). With BIM driving revolution and changing roles of professionals in the construction industry, Hungu (2013) believes that sustainability information based on BIM simulation is required during early design stage. Also, AGCA (2006) states that changes are part of the building process and that change management plan must be part of the information required in a Building Information Model as this will allow the project team members to modify and disseminate the information that they are responsible for. This shows that the traditional roles of builders in project delivery have not been totally changed but revolutionised by BIM.

\section{Builders and Their Roles in the Nigerian Construction Industry}

The building construction industry in Nigeria started in the 1930s (Mbamali and Okotie, 2012). The industry has an output of about $11 \%$ of Gross Domestic Product (GDP) and employs about one over three percentages of workers in Nigeria (National Housing Policy, 2006). In the building construction industry, builders are the building contractors that execute construction projects. They are liable to the clients directly in all the stages of building contracts, ranging from contract award, material procurement, site operations and project delivery (Funmilola et al., 2013). The Nigerian Institute of Building (2014) describes a registered builder as a professional who has received an approved standard of professional training and practice in building and found competent after due examination.

According to The Nigerian Building Site (2017), the different categories of services requiring the appointment of a registered or professional builders include: production/construction management of building projects, management of direct labour projects, building surveying, report on abandoned projects, maintenance management of building and associated infrastructure, resident supervision of building projects, expert witness on litigation and arbitration arising out of building 
projects, feasibility and viability studies on building projects, project management, management contracting and project monitoring and evaluation.

\section{Level of BIM usage in Nigeria Construction Industry}

The use of level 0 and 1 BIM in the Nigerian construction industry have been widely reported by authors like Oladapo (2006), Ede (2014), Olayiwola (2008), Oladapo (2007), Ibironke et al. (2011), Olalusi and Jesuloluwa (2013), Dare-Abel et al. (2014), Idowu et al. (2012), Abubakar (2006), Olukayode and Adeyemi (2011), Oyediran and Odusami (2005) and Simolowo et al. (2010). Ede (2014) specifically reported the case study of a duplex building in Enugu State, Nigeria, where BIM was used. He reported that Computer-Aided-Design (CAD) softwares like Navisworks Manage 2013, Autodesk Revit 2014, Orion, Robot, Staa-Pro and Civil Soft were made use of by the project team members. Collaboration among the project team members was enabled by the use of information and communication technologies (ICT). Olalusi and Jesuloluwa (2013) studied the impact of information technology on Nigerian construction industry and found that information technology is well oriented in Nigeria as the level of BIM software utilisation is high. Olukayode and Adeyemi (2011) in a survey of the art of e-tendering in Nigeria found that $27.3 \%$ of professionals are using network software, $30.3 \%$ has web presence for collaborating and communicating with other project members, $24.2 \%$ has mailing software facility, 27.3\% using MasterBill software, $69.7 \%$ using AutoCAD and $24.2 \%$ using WinQS. The study concluded that the use of ICT is usually intended to enable collaboration in construction business process. Oyediran and Odusami (2005) studied the extent of software technologies usage by Nigerian Quantity Surveyors and found that the usage of professional softwares such as MasterBill, QS Elite, WinQS, Snape and Catopro is very high. The study also found cost modelling and bill preparation as some of the impact of ICT on quantity surveying (QS) roles. In a survey of 159 architectural firms in six selected cities in Nigeria, namely Abuja, Kaduna, Maiduguri, Enugu, Lagos and Port Harcourt, to study the proficiency and capacity building of human capital in architectural firms. Dare-Abel et al. (2014) found that $30.5 \%$ of the firms had sufficient BIM proficient staff but do not run a staff training programme while $32.2 \%$ of the firms had sufficient BIM proficient staff and also run a staff training programme for BIM. Idowu et al. (2012) reported a comparative study of information technology (IT) benefits in construction industry in Malaysia and Nigeria; the study concluded that the use of CAD has become normal practice within the Nigerian construction industry. This conclusion buttressed that of Usman et al. (2012) and Ibironke et al. (2011) with a conclusion that Nigeria has experienced two decades of continuous adoption of ICT.

Ibironke et al. (2011) studied the level and impact of usage of ICT among QS in Nigeria; the study reached the same conclusion with Oyediran and Odusami (2005). In a study of status and impact of CAD/Computer-Aided-Manufacturing (CAM) applications in Nigerian Industrial Sector, Simolowo et al. (2010) found that AutoCAD, 3D-Studio and Civil works are the commonly used BIM software technologies in Nigeria. Oladapo $(2006 ; 2007)$ investigated the impact of ICT on professional practice and usage of ICT in the Nigerian construction industry; his findings contradicted the expectations of researchers on the level of usage of discipline-specific CAD softwares by construction professionals in Nigeria. Similarly, Olayiwola (2008) examined the level of awareness and use of ICT in supply chain 
management in the Nigerian construction industry. His findings supported that of Oladapo (2006) and also identified the use of internet as an efficient information exchange platform in the Nigerian construction industry. He further concluded that the professionals in construction supply chain in Nigeria have little knowledge in the use of each other's discipline-specific software technologies.

The findings of studies by Oladapo (2006), Ede (2014), Olayiwola (2008), Oladapo (2007), Ibironke et al. (2011), Olalusi and Jesuloluwa (2013), Dare-Abel et al. (2014), Idowu et al. (2012), Abubakar (2006), Olukayode and Adeyemi (2011), Oyediran and Odusami (2005) and Simolowo et al. (2010) revealed that the construction professionals in the Nigerian construction industry understood BIM as 2-dimensional (2D) and 3-dimensional (3D) CAD; whereas BIM involves the usage of software technologies (CAD), undertaking collaborative processes and adherence to protocols and guidelines. Only the usage of software technologies have been extensively reported in the Nigerian construction industry, which is an indication of low level of BIM usage in the Nigerian construction industry.

\section{RESEARCH METHOD}

Primary data was required for the study and was obtained through a structured questionnaire survey approach. The target population was composed of only the registered builders in Nigeria. A total of 132 questionnaires filled by the respondents were used for analysis. Respondents were requested to indicate their responses on a five-point Likert scale ranging from "Strongly agree" (SA) to "Strongly disagree" (SD). Data collected were analysed using clustered bar chart, frequency distribution and percentage and Relative Importance Index (RII). RII was used to examine and rank the statements in terms of their criticality as perceived by the respondents. The RII was computed using the formula below. To determine the relative ranking of the criteria, the scores were transformed to important indices based on the formula:

$$
\mathrm{RII}=\frac{\sum \mathrm{W}}{\mathrm{AN}}=\frac{5 n_{5}+4 n_{4}+3 n_{3}+2 n_{2}+1 n_{1}}{5 N}
$$

where $W$ is the weight given to each factor by the respondent, ranging from 0 to $5,\left(n_{5}=\right.$ number of respondents for strongly agree, $n_{4}=$ number of respondents for Agree, $n_{3}=$ number of respondents for neutral, $n_{2}=$ number of respondents for disagree and $n_{1}=$ number of respondents for strongly disagree). $A$ is the highest weight (i.e. 5 in this study) and $N$ is the total number of samples (respondents). The Rll ranges from zero to one.

\section{FINDINGS AND DISCUSSION OF FINDINGS}

As presented in Table 1, the project managers accounted for the simple majority $(25.0 \%)$ of the total respondents surveyed. This was followed by principal technical officers, accounting for (15.9\%), while the site managers accounted for the least proportion (6.1\%) of the total respondents surveyed. Simple majority (39.4\%) of the total respondents surveyed holds Bachelor of Science (BSC) degree (Table 1), while higher national diploma and diploma students, each accounted for $27.7 \%$ and 27.3\% respectively. National diploma (ND) and PhD holders each accounted for 
just $3.0 \%$ of the total respondents surveyed. This implies that the respondents possess substantial academic qualification which could guarantee their understanding of the questions directed to them and subsequently established the originality of the data obtained for the study.

Table 1. Profile of Respondents

\begin{tabular}{lc}
\hline Profile of Respondents & Percentage \\
\hline Designation of Respondents & \\
Managing director & $6.1 \%$ \\
Site supervisor & $12.1 \%$ \\
Consulting builder & $11.4 \%$ \\
Trainee site manager & $12 \%$ \\
Project manager & $25 \%$ \\
Head of site & $12.9 \%$ \\
Principal technical officer & $15.9 \%$ \\
Academic Qualifications of Respondents & \\
Doctor of philosophy & $3 \%$ \\
Master of science & $27.3 \%$ \\
Bachelor of science & $39.4 \%$ \\
Higher national diploma & $27.7 \%$ \\
Ordinary national diploma & $3 \%$ \\
Level of Membership of Respondents in the Nigerian Institute of $3 \mathrm{Bilding}$ \\
Graduate member & $3 \%$ \\
Student member & $3 \%$ \\
Fellow & $3 \%$ \\
Corporate member & $81.8 \%$ \\
Working Experience and Number of Projects Involved in by Respondents \\
21 years and above & $24.2 \% / 15.2 \%$ \\
$16-20$ years & $21.2 \% / 6.1 \%$ \\
$11-15$ years & $12.10 \% / 24.2 \%$ \\
$5-10$ years & $27.3 \% / 36.4 \%$ \\
Less than five years & $15.2 \% / 18.2 \%$ \\
\hline
\end{tabular}

Table 1 also reveals that significant proportion of the surveyed respondents are Members of Nigerian Institute of Building (MNIOB) $(81.8 \%)$, while the remaining surveyed respondents belong to corporate, student and graduate members of $\mathrm{NIOB}$, each accounting for $3.0 \%$. Simple majority $(36.4 \%)$ of the surveyed respondents had between 5-10 years of work experience (Table 1), followed by those with 11-15 years of work experience, accounting for $24.2 \%$, while the least proportion $(6.1 \%)$ was observed among respondents with 16-20 years of work experience. Table 1 also shows that simple majority (27.3\%) of the respondents had been involved in about 5-10 projects, followed by respondents who had been involved in over 20 projects, accounting for $24.2 \%$. The least proportion was observed among respondents who had been fully involved in about 11-15 projects, accounting for $12.1 \%$. This findings show that the surveyed respondents had sufficient qualifications and experience to respond adequately to the research questions. 
Table 2. Information Required from Builders in BIM Processes

\begin{tabular}{lccccccc}
\hline $\begin{array}{l}\text { Information Required from Builders } \\
\text { in BIM Processes }\end{array}$ & $\begin{array}{c}\text { SD } \\
\mathbf{( 1 )}\end{array}$ & $\begin{array}{c}\text { D } \\
\mathbf{( 2 )}\end{array}$ & $\begin{array}{c}\mathbf{N} \\
\mathbf{( 3 )}\end{array}$ & $\begin{array}{c}\text { A } \\
\mathbf{( 4 )}\end{array}$ & $\begin{array}{c}\text { SA } \\
\mathbf{( 5 )}\end{array}$ & RII & Rank \\
\hline Construction programme & 4 & 12 & 8 & 16 & 92 & 0.87 & 1 \\
Construction methodology & 12 & 0 & 12 & 20 & 88 & 0.86 & 2 \\
Buildability analysis report & 8 & 4 & 8 & 44 & 68 & 0.84 & 3 \\
Maintainability analysis report & 0 & 4 & 24 & 56 & 48 & 0.82 & 4 \\
Constructability analysis report & 12 & 12 & 8 & 44 & 56 & 0.78 & 5 \\
Sustainability analysis report & 8 & 8 & 24 & 60 & 32 & 0.75 & 6 \\
Function analysis report & 0 & 28 & 56 & 24 & 24 & 0.67 & 7 \\
\hline
\end{tabular}

Notes: $\mathrm{SD}=$ Strongly Disagree, $\mathrm{D}=$ Disagree, $\mathrm{N}=$ Neutral, $\mathrm{A}=$ Agree, $\mathrm{SA}=$ Strongly Agree .

Table 2 presents the survey data on respondents' levels of agreement with information required from builders towards collaboration on BIM for building projects. The data reveals that construction programme ranked first with Rll of 0.87 , followed by construction methodology ( $R \|=0.86)$, buildability analysis report $(R I I=0.84)$, while function analysis report was ranked least $(R I=0.67)$ by the surveyed respondents. The low level of agreement with function analysis report as one of the major roles of builders by the surveyed respondents is consistent with the earlier studies by AGCA (2006). The high rank of construction programme and construction methodology by the respondents is in line with the conclusions of CURT (2010) that identified construction management information and construction methodology as the most important information to be developed for construction management of projects.

Table 3. Order of Developing the Information Required from Builders in BIM Processes

\begin{tabular}{|c|c|c|c|c|c|c|c|c|c|c|c|c|}
\hline \multirow{2}{*}{$\begin{array}{l}\text { Information Required from } \\
\text { Builders in BIM Processes }\end{array}$} & \multicolumn{6}{|c|}{ Conceptual Design Stage } & \multicolumn{6}{|c|}{ Planning Design Stage } \\
\hline & $\begin{array}{c}S D \\
1\end{array}$ & $\begin{array}{l}\text { D } \\
2\end{array}$ & $\begin{array}{l}\mathbf{N} \\
3\end{array}$ & $\begin{array}{l}\text { A } \\
4\end{array}$ & $\begin{array}{c}\text { SA } \\
5\end{array}$ & RII & $\begin{array}{c}S D \\
1\end{array}$ & $\begin{array}{l}\text { D } \\
2\end{array}$ & $\begin{array}{l}\mathbf{N} \\
3\end{array}$ & $\begin{array}{l}A \\
4\end{array}$ & $\begin{array}{c}\text { SA } \\
5\end{array}$ & RII \\
\hline Function analysis report & 12 & 4 & 44 & 16 & 40 & 0.72 & 0 & 0 & 8 & 4 & 4 & 0.75 \\
\hline Sustainability analysis report & 0 & 12 & 36 & 32 & 24 & 0.73 & 0 & 0 & 4 & 12 & 12 & 0.86 \\
\hline Maintainability analysis report & 0 & 12 & 40 & 16 & 32 & 0.74 & 0 & 0 & 0 & 8 & 24 & 0.95 \\
\hline Constructability analysis report & 0 & 8 & 24 & 24 & 40 & 0.80 & 0 & 0 & 4 & 4 & 24 & 0.93 \\
\hline Buildability analysis report & 8 & 4 & 20 & 12 & 56 & 0.81 & 0 & 0 & 4 & 8 & 20 & 0.90 \\
\hline Construction programme & 0 & 8 & 0 & 0 & 0 & 0.40 & 4 & 4 & 8 & 20 & 88 & 0.92 \\
\hline Construction methodology & 8 & 0 & 0 & 0 & 0 & 0.20 & 0 & 4 & 8 & 24 & 88 & 0.93 \\
\hline
\end{tabular}

Table 3 shows the respondents level of agreement with the order of developing the information required from builders in BIM processes. At the conceptual design stage, buildability analysis report was ranked first with Rll of 0.81 , closely followed by constructability analysis report with RII of 0.80 . Maintainability analysis report, sustainability analysis report, function analysis report and construction programme 
were ranked third, fourth, fifth and sixth with RII of $0.74,0.73,0.72$ and 0.40 respectively. Construction methodology with RIl of 0.20 ranked least at the conceptual stage. At the planning stage, respondents agreed that maintainability analysis report with RII of 0.95 should be the first information to be developed. Constructability analysis report and construction methodology with RII of 0.93 ranked second as the next information required at the planning stage. In addition, construction programme $(R \|=0.92)$, buildability analysis report $(R \|=0.90)$, sustainability analysis report $(R \|=$ 0.86 ) and function analysis report (RII $=0.75$ ) were ranked third, fourth, fifth and sixth respectively by the respondents.

Given the low level of agreement of respondents with function analysis report based on its Rll of 0.67 in Table 2 and 0.72 in Table 3. It can be seen that respondents are not of the opinion that function analysis of projects is solely the responsibilities of builders. As found by Kam and Fisher (2004), function analysis of projects requires the builders to collaborate with the project team members in order to generate design options with relevant building systems alternatives and other works that add value to the client. Comparing the RIl of the sections of construction and management information model at the conceptual design stage and planning stage; it can be seen that the sections are favored by the respondents to be developed at the planning stage where critical decision-making will take place. This finding is consistent with the recent study by Rangelova and Traykova (2014) which indicated that project information models are to be developed right from the design stage but are mainly required in the planning stage to enhance decision-making.

Table 4. Contents of Information Required from Builders in BIM Processes

\begin{tabular}{|c|c|c|c|c|c|c|c|c|}
\hline & $\begin{array}{c}\text { SD } \\
1\end{array}$ & $\begin{array}{l}\mathrm{D} \\
2\end{array}$ & $\begin{array}{l}N \\
3\end{array}$ & $\begin{array}{l}A \\
4\end{array}$ & $\begin{array}{c}\text { SA } \\
5\end{array}$ & Total & RII & Rank \\
\hline Construction Programme & \multicolumn{8}{|c|}{$R \|=0.65$} \\
\hline Time schedule & 8 & 0 & 4 & 48 & 72 & 132 & 0.87 & 1 \\
\hline Quality management plan & 4 & 8 & 8 & 44 & 68 & 132 & 0.85 & 2 \\
\hline Resource schedule & 8 & 8 & 4 & 48 & 64 & 132 & 0.83 & 3 \\
\hline Cash flow plan & 4 & 8 & 20 & 36 & 64 & 132 & 0.82 & 4 \\
\hline Site utilisation plan & 4 & 8 & 12 & 56 & 52 & 132 & 0.82 & 4 \\
\hline Communication plan & 4 & 12 & 12 & 48 & 56 & 132 & 0.81 & 5 \\
\hline Transition and closure plan & 8 & 4 & 32 & 40 & 48 & 132 & 0.78 & 6 \\
\hline Change management plan & 8 & 8 & 24 & 52 & 40 & 132 & 0.76 & 7 \\
\hline Construction Methodology & \multicolumn{8}{|c|}{$\mathrm{RII}=0.60$} \\
\hline Construction plan & 0 & 8 & 4 & 40 & 80 & 132 & 0.89 & 1 \\
\hline Health and safety management plan & 0 & 8 & 12 & 44 & 68 & 132 & 0.86 & 2 \\
\hline Material management plan & 8 & 4 & 8 & 32 & 80 & 132 & 0.86 & 2 \\
\hline Method statement & 4 & 12 & 8 & 32 & 76 & 132 & 0.85 & 3 \\
\hline Scope of work & 4 & 8 & 20 & 28 & 72 & 132 & 0.84 & 4 \\
\hline Manpower plan & 4 & 12 & 4 & 48 & 64 & 132 & 0.84 & 4 \\
\hline Best management practices (BMP) plan & 8 & 0 & 16 & 48 & 60 & 132 & 0.83 & 5 \\
\hline
\end{tabular}


Table 1. (continued)

\begin{tabular}{|c|c|c|c|c|c|c|c|c|}
\hline & $\begin{array}{c}S D \\
1\end{array}$ & $\begin{array}{l}\mathrm{D} \\
2\end{array}$ & $\begin{array}{l}\mathbf{N} \\
3\end{array}$ & $\begin{array}{l}\text { A } \\
4\end{array}$ & $\begin{array}{c}\text { SA } \\
5\end{array}$ & Total & RII & Rank \\
\hline Constructability Analysis Report & \multicolumn{8}{|c|}{$\mathrm{RII}=0.57$} \\
\hline $\begin{array}{l}\text { Consideration of construction methods } \\
\text { and specification }\end{array}$ & 4 & 8 & 4 & 52 & 64 & 132 & 0.85 & 1 \\
\hline $\begin{array}{l}\text { Integration systems for architectural, } \\
\text { engineering, construction and other } \\
\text { information model. }\end{array}$ & 4 & 4 & 8 & 60 & 56 & 132 & 0.84 & 2 \\
\hline $\begin{array}{l}\text { Use of construction knowledge and } \\
\text { innovation }\end{array}$ & 8 & 8 & 4 & 52 & 60 & 132 & 0.82 & 3 \\
\hline Team composition and skills & 8 & 8 & 8 & 60 & 48 & 132 & 0.80 & 4 \\
\hline Constructability score & 4 & 12 & 20 & 44 & 52 & 132 & 0.79 & 5 \\
\hline $\begin{array}{l}\text { Construction accessibility and resource } \\
\text { availability }\end{array}$ & 12 & 0 & 16 & 64 & 40 & 132 & 0.78 & 6 \\
\hline Procurement strategy & 4 & 8 & 32 & 52 & 36 & 132 & 0.76 & 7 \\
\hline Sustainability Analysis Report & \multicolumn{8}{|c|}{$\mathrm{R} \|=0.55$} \\
\hline Water conservation & 0 & 4 & 12 & 52 & 64 & 132 & 0.87 & 1 \\
\hline $\begin{array}{l}\text { Sustainability score (determined from } \\
\text { sustainability criteria) }\end{array}$ & 4 & 8 & 12 & 76 & 32 & 132 & 0.79 & 2 \\
\hline Surrounding environment & 4 & 12 & 4 & 80 & 32 & 132 & 0.79 & 2 \\
\hline Sustainable materials & 4 & 12 & 12 & 64 & 40 & 132 & 0.79 & 2 \\
\hline Indoor environment quality & 4 & 12 & 16 & 68 & 32 & 132 & 0.77 & 3 \\
\hline Design flexibility & 12 & 4 & 16 & 68 & 32 & 132 & 0.76 & 4 \\
\hline Energy efficiency & 8 & 4 & 32 & 56 & 32 & 132 & 0.75 & 5 \\
\hline Maintainability Analysis Report & \multicolumn{8}{|c|}{$\mathrm{RII}=0.47$} \\
\hline $\begin{array}{l}\text { Maintainability score (determined from } \\
\text { maintainability report) }\end{array}$ & 0 & 8 & 16 & 64 & 44 & 132 & 0.82 & 1 \\
\hline Reliability of components and materials & 0 & 12 & 20 & 44 & 56 & 132 & 0.82 & 1 \\
\hline Maintenance manual & 8 & 4 & 16 & 52 & 52 & 132 & 0.81 & 2 \\
\hline Availability of spare parts and accessibility & 4 & 12 & 24 & 56 & 36 & 132 & 0.76 & 3 \\
\hline Tolerable downtown & 4 & 12 & 32 & 56 & 28 & 132 & 0.74 & 4 \\
\hline Mean time to repair (MTTR) estimates & 8 & 16 & 36 & 40 & 32 & 132 & 0.71 & 5 \\
\hline Buildability Analysis Report & \multicolumn{8}{|c|}{$\mathrm{R} \|=0.47$} \\
\hline Dimensional coordination and tolerance & 4 & 0 & 20 & 52 & 56 & 132 & 0.84 & 1 \\
\hline Buildability & 0 & 8 & 24 & 48 & 52 & 132 & 0.82 & 2 \\
\hline $\begin{array}{l}\text { Handling, erection and assemblage } \\
\text { difficulties }\end{array}$ & 8 & 0 & 32 & 52 & 40 & 132 & 0.78 & 3 \\
\hline Omissions, errors and clashes in information & 4 & 16 & 28 & 40 & 44 & 132 & 0.76 & 4 \\
\hline Variety of design & 4 & 12 & 32 & 44 & 40 & 132 & 0.76 & 4 \\
\hline Excessive conversion of materials & 8 & 20 & 32 & 36 & 36 & 132 & 0.71 & 5 \\
\hline
\end{tabular}


Table 1. (continued)

\begin{tabular}{|c|c|c|c|c|c|c|c|c|}
\hline & $\begin{array}{c}S D \\
1\end{array}$ & $\begin{array}{l}\mathrm{D} \\
2\end{array}$ & $\begin{array}{l}\mathbf{N} \\
3\end{array}$ & $\begin{array}{l}\text { A } \\
4\end{array}$ & $\begin{array}{c}\text { SA } \\
5\end{array}$ & Total & RII & Rank \\
\hline Function Analysis Report & \multicolumn{8}{|c|}{$\mathrm{R} \|=0.31$} \\
\hline $\begin{array}{l}\text { Identification and definition of the } \\
\text { functions of spaces, elements and } \\
\text { components within projects. }\end{array}$ & 0 & 8 & 24 & 44 & 56 & 132 & 0.82 & 1 \\
\hline Project function definition & 8 & 8 & 16 & 44 & 56 & 132 & 0.80 & 2 \\
\hline $\begin{array}{l}\text { List of alternative solutions to the spaces, } \\
\text { elements and components }\end{array}$ & 8 & 4 & 36 & 48 & 36 & 132 & 0.75 & 3 \\
\hline $\begin{array}{l}\text { Ratings of alternatives against selection } \\
\text { criteria }\end{array}$ & 0 & 12 & 52 & 36 & 32 & 132 & 0.73 & 4 \\
\hline
\end{tabular}

Table 4 shows the survey data on respondents' level of agreement on contents of information required from builders in BIM processes. The contents of information required from builders in BIM processes as identified by the respondents were consistent with other studies from Jensen (2008) and Kuroshi (2015). Again, construction programme $(\mathrm{R} \|=0.65)$ and construction methodology $(\mathrm{R} \|=0.60)$ were rated high, similar to the RII of 0.89 and 0.86 found in Table 2 . The information contents that were rated high in construction programme were time schedule (0.87), quality management plan (0.85) and resource schedule (0.83). Change management plan was rated least with RII of 0.76; while cash flow plan and site utilisation plan, communication plan and transition and closure plan ranked fourth, fifth and sixth with RII of $0.82,0.81$ and 0.78 respectively as the required information contents in construction programme.

In construction methodology, construction plan ranked first with Rll of 0.89 ; while health and safety management plan and material management plan ranked second with RIl of 0.86. Ranked third, fourth and fifth are method statement (RII $=0.85)$, scope of work and manpower plan $(\mathrm{R} \|=0.84)$ and best management practices plan (RII = 0.85) respectively. In constructability analysis report, the ratings show that consideration of construction methods and specification (RII $=0.85)$, integration systems for architectural, engineering, construction and other information model (RII $=0.84)$ and use of construction knowledge and innovation (R\| $=0.82$ ) were highly agreed to be the main information contents of constructability analysis report. The least rated information contents in constructability analysis report is procurement strategy with RII of 0.76 .

In sustainability analysis report, the information contents were ranked into five. Water conservation was rated first with Rll of 0.87 ; sustainability score, surrounding environment and sustainability materials were rated second with RII of 0.79; indoor environment quality was rated third with RII of 0.77 ; while design flexibility and energy efficiency were rated fourth and fifth with RII of 0.76 and 0.75 respectively. With respect to maintainability analysis report and buildability analysis report, the information contents were ranked into five. In maintainability analysis report, maintainability score and reliability of components and materials ranked first with RIl of 0.82 and maintenance manual ranked second with RII of 0.81. MTTR estimates ranked fifth with RII of 0.71 in buildability analysis report. Variety of design and omissions, errors and clashes in information ranked fourth with Rll of 0.76 and handling, erecting and assemblage difficulties ranked third with RII of 0.78 . Ranked first with RIl of 0.84 is dimensional coordination and tolerance. 
In function analysis report, identification and definition of the functions of spaces ranked least with RII of 0.31 . Elements and components within projects ranked first with RII of 0.82 , project function definition ranked second with Rll of 0.80 , while list of alternative solutions to the spaces, elements and components ranked third with RII of 0.75. Ratings of alternatives against selection criteria ranked fourth with RII of 0.73. As previously highlighted by NBIM Standard (2007) and CIC (2013), the information contents of an information model must be defined and based on the needs of projects. The finding of this study as shown Tables 2, 3 and 4 indicate that information required from builders in BIM processes and contents of these information are subject to the needs and stages of projects.

Accordingly, the study by Sebastian (2010), Simpson (2013) and Velasco (2013) noted that to take the level of information contents in a Building Information Model to the 4th dimension (4D), the builder needs to inspect the information models developed by architects and engineers in 3D for interferences, errors and omissions. The roles of builders as identified from the findings of this study are consistent with these earlier studies and can therefore be consolidated into two main roles as required in BIM processes. The first role of builders in BIM is the coordination of 3D models developed by architects and engineers to detect clashes in accordance with the buildability, constructability and maintainability analysis required for the project. In BIM, the other role of builders is the simulation of the construction process in a sequential order according to the proposed construction programme, construction methodology and sustainability analysis and function analysis report.

\section{CONCLUSION}

Information required from builders in BIM processes consist mainly the construction programme, construction methodology, buildability analysis report and maintainability analysis report. Other information that may be required from builders are constructability analysis report, sustainability report and function analysis report. The development of these information should start at the conceptual design stage but must be ready at the planning stage for critical decision-making. The order of preparation should be maintainability analysis report, constructability analysis report, construction methodology, construction programme, buildability analysis report, sustainability analysis report and function analysis report.

These information models should contain time schedule, quality management plan, resource schedule, cash flow plan, site utilisation plan and communication plan in the construction programme section. For construction methodology, the information content should include construction plan, health and safety management plan, material management plan, method statement, scope of work, manpower plan and best management practices plan. In constructability analysis report section, the information contents should include consideration of construction methods and specification, integration systems for other information models, use of construction knowledge and innovation, team composition and skills and constructability score.

Furthermore, in sustainability analysis report section, the information contents should include water conservation, sustainability score, surrounding environment, sustainable materials, indoor environment quality, design flexibility and energy efficiency. Also, in the maintainability analysis report, the information content should include maintainability score, reliability of components and materials, maintenance 
manual, availability of spare parts and accessibility, tolerable downtown and MTTR estimates. Dimensional coordination and tolerance, buildability, handling and assemblage difficulties, omissions and clashes in information, variety of design and excessive conversion of materials should be included in buildability analysis report.

Finally, in function analysis report section, the information contents should be identification and definition of the findings of spaces and components within projects, project function definition, list of alternative solutions to the spaces and components and ratings of alternatives against selection criteria. However, the information required from builders in BIM processes can be used to define the specific roles of builders in BIM. These information and their contents can be summarised as information clashes and errors detection, development of time model (4D model) and simulation of the construction process based on the health and safety management model, manpower utilisation model, quality management model, site utilisation model and BMP plan. The specific roles of builders in BIM processes are linked with the roles of other professionals in the construction industry. For example, information clashes and errors detection requires the input of architects and engineers; for the reason that, it is the architectural information model and engineering information model that would be analysed for clash detection. The cost information model to be developed by the quantity surveyor is required for the development of manpower utilisation model. Also, developing quality management and time model requires the 3D models to be developed by the architects and engineers.

Builders are required to develop these information models as part of the discipline-specific information models required in building information models. However, it should be noted that the development of these information models requires builders to be proficient in the usage of software technologies such as MS Project or Primavera, Autodesk Naviswork, Autodesk Revit and Civil Soft. MS Project is required for creating time models, Naviswork for conducting clash detection and creating 4D models, Civil Soft for creating site utilisation models, while Autodesk Revit is required for simulating the construction methods and processes and for creating manpower utilisation model.

\section{REFERENCES}

Abubakar, S. (2006). Evolution of the computer as a tool of design in architecture. AARCHES Journal, 5(2): 47-58.

Arcadis (2015). BIM According to Arcadis. Amersfoort, Netherlands: Arcadis.

Associated General Contractors of America (2006). The Contractors' Guide to BIM. Virginia: Associated General Contractors of America.

Bullinger, H.J., Baver, W., Wenzel, G. and Blach, R. (2010). Towards user centred design (UCD) in architecture based on immersive virtual environments. Computers in Industry, 61 (4): 372-379. https://doi.org/10.1016/j.compind.2009.12.003.

Chen, Q. (2007). An object model framework for interface management in Building Information Models. PhD diss. Virginia Polytechnic Institute and State University.

Construction Industry Council (2013). Building Information Model Protocol: Standard Protocol for Use in Projects Using Building Information Models. London: Construction Industry Council. 
Dare-Abel, O.A., Ayo, C.K. and Omoregbe, N.I. (2014). Acceptance of Computer Supported Collaborative Work (CSCW) in architectural firms in Nigeria. The International Journal of Engineering and Science, 3(7): 1-8.

Eastman, C., Teicholz, P., Sacks, R. and Liston, K. (2008). BIM Handbook. Hoboken, NJ: John Wiley and Sons, Inc. https://doi.org/10.1002/9780470261309.

Ede, A.N. (2014). Building Information Modeling: Case study of a duplex building project in Nigeria. International Journal of IT, Engineering and Applied Sciences Research (IJIEASR), 3(4): 25-28.

Funmilola, A.B., Onajite, J.G., Kehinde, O.G. and Julius, O.S. (2013). Level of compliance of core construction professionals to ethical standards in Nigeria. Global Journal of Management and Business Research Administration and Management, 13(12): 27-36.

Hungu, C.F. (2013). Utilization of BIM from early design stage to facilitate efficient FM operations. MSc diss. Chalmers University of Technology.

Ibironke, O.I., Ekundayo, D. and Awodele, O.A. (2011). A survey on the use and impact of information technology in quantity surveying service delivery in Nigeria. In C. Egbu and E.C.W. Lou (eds.), Proceedings of 27th Annual: Association of Researchers in Construction Management (ARCOM) Conference. Bristol, UK: ARCOM, 433-442.

Idowu, O.B., lyagba, R.O.A. and Gambo, Y.L. (2012). A comparative study of IT benefits in construction industry in Malaysia and Nigeria. Elixir Social Science, 52: 11389-11396.

Jensen, P.A. (2008). Integration of consideration for facilities management in design. In Design Management in the Architectural Engineering and Construction Sector: CIB W096 Architectural Management and TG49 Architectural Engineering. Rotterdam: CIB, 191-199.

Jung, Y. and Joo, M. (201 1). BIM framework for practical implementation. Automation in Construction, 20(2): 126-133. https://doi.org/10.1016/j.autcon.2010.09.010.

Kam, C. and Fisher, M. (2004). Capitalizing on early project decision-making opportunities to improve facility design, construction and life-cycle performance-POP, PM4D and decision dashboard approaches. Automation in Construction, 13(1): 53-65. https://doi.org/10.1016/j.autcon.2003.08.004.

Khanzode, A., Fisher, M. and Reed, D. (2008). Benefits and lessons learned of implementing building virtual design and construction (VDC) technologies for coordination of mechanical, electrical and plumbing (MEP) systems on a large healthcare project. ITcon, 13(Special issue: Case studies of BIM use): 324-342

Kuroshi, P. (2015). Construction practices and skills gap in the construction industry. Paper presented at the Builders' Conference/Annual General Meeting Oluyole 2015. Abuja, Nigeria.

Mbamali, I. and Okotie, A.J. (2012). An assessment of the threats and opportunities of globalization in building practice in Nigeria. American International Journal of Contemporary Research, 2(4): 143-150.

National Institute of Building Sciences (2007). National Building Information Modeling Standard (NBIMS) Version 1.0: Part 1; Overview, Principles and Methodology. Washington DC: National Institute of Building Sciences.

Nigerian Institute of Building (NIOB) (2014). Who is a Registered Builder? Abuja: NIOB. Available at: www.niobnat.org.ng/portal/frontend/\#tab-4 [Accessed on 22 March 2017]. 
Nikumbh A.R. and Pimplikar S.S. (2014). Role of project management consultancy in construction project. IOSR Journal of Mechanical and Civil Engineering, 10(6): 14-19. https://doi.org/10.9790/1684-1061419.

Oladapo, A.A. (2007). An investigation into the use of ICT in the Nigerian construction industry. ITcon, 12: 261-277.

(2006). The impact of ICT on professional practice in the Nigerian construction industry. The Electronic Journal on Information Systems in Developing Countries, 24(2): 1-19. https://doi.org/10.1002/j.1681-4835.2006. tb00157.x.

Olalusi, O.C. and Jesuloluwa, O. (2013). The impact of information technology on Nigerian construction industry. International Journal of Engineering and Innovative Technology, 2(9): 1-5.

Olayiwola, M.K.A. (2008). The level of awareness and use of ICT in supply chain management in the Nigerian construction industry. Building Abroad, October.

Olukayode, S.O. and Adeyemi, A.A. (2011). A survey of the state of the art of e-tendering in Nigeria. ITcon, 16: 557-576.

Oyediran, O.S. and Odusami, K.T. (2005). A study of computer usage by Nigerian quantity surveyors. ITcon, 10: 291-303.

Rangelova, F. and Traykova, M. (2014). Value management in construction project. Paper presented at the First Scientific-Applied Conference with International Participation "Project Management in Construction". University of Architecture, Civil Engineering and Geodesy, Sofia, Bulgaria, 4-5 December.

Royal Institute of British Architects (RIBA) (2012). BIM Overlay to the RIBA Outline Plan of Work. London: RIBA Publishing.

Sebastian, $R$ (2010). Breaking through business and legal barriers of open collaborative processes based on building information modelling (BIM). Paper presented at the WI 13-Special Track 18th CIB World Building Congress. Salford, United Kingdom.

Simolowo, O.E., Okonkwo, F.C. and Kehinde, O.O. (2010). CAD/CAM applications: status and impact in Nigerian industrial sector. Indian Journal of Science and Technology, 3(6): 648.

Simpson, M. (2013). A definition of BIM. The Structural Engineer, November.

Specialist Engineering Contractors' (SEC) Group and National Specialist Contractors' Council (NSCC) BIM Working Group (2013). First Steps to BIM Competence: A Guide for Specialist Contractors. Newcastle, England: SEC Group in collaboration with the BIM Academy, University of Northumbria. Available at: https://www.thefis.org/wp-content/uploads/2016/09/BIM-Guide-2014-1.pdf.

Succar, B. (2008). BIM framework: A research and delivery foundation for industry stakeholders. Automation in Construction, 18(3): 357-375. https://doi.org/ 10.1016/j.autcon.2008.10.003.

The Computer Integrated Construction Research Group (2010). BIM Project Execution Planning Guide, Version 2.0. Pennsylvania: The Pennsylvania State University.

The Construction Users Roundtable (CURT) (2010). BIM Implementation: An Owner's Guide to Getting Started. Cincinnati, OH: CURT.

The Nigerian Building Site (2017). Who is a Professional Builder? Abuja: The Nigerian Building Site. Available at: www.thenigerianbuilding.com/professional-builder [Accessed on 22 March 2017]. 
Usman, N.D., Inuwa, I.I. and Iro, A.I. (2012). The influence of unethical professional practices on the management of construction projects in north-eastern states of Nigeria. International Journal of Economic Development Research and Investment, 3(2): 124-129.

Velasco, A.U. (2013). Assessment of 4D BIM applications for project management functions. MSC diss. University of Cantabria. 